\title{
Myth versus History in Contemporary Irish Poetry
}

\author{
Péter Dolmányos
}

In the poem entitled "Outside History", Eavan Boland's speaker makes an assertion that is the expression of a rather clear-cut choice: "I have chosen: // out of myth into history I move" (Boland 188). The poem initially focuses on the state of stars as being "outside history", indicating the speaker's interest in experience that is marked by time, and as the poem is the closing piece of a sequence with several mythic figures, the contrast is established not between the celestial and earthly realms but between human constructs that would be marked by different relations to the concept of time, namely myth and history. The temporal situation of myth retains an element of ambiguity: as a narrative it refers to an undefined time yet its internal logic of timekeeping is comprehensible in human terms, akin to history. At the same time, it provides a contrast with history as its implication of the divine creates the impression of time distanced and suspended, thus its relation to human experience represents another type of approach compared to that of history. It is rather this difference between what could be best termed the timeless versus the temporal that is emphasised by the explicit choice in the quotation.

On the surface, the assertion of the speaker does little more than indicate the presence and validity of both these concepts in Irish poetry as elements in relation to which a particular instance of human experience can be measured. On closer scrutiny, however, the contrast that exists between them and the importance of the choice and preference of the one over the other reveal certain concerns regarding the type of analogy these two terms may provide for assessing experience. The direction of the move expressed by the speaker is from myth to history, which suggests the intention of a tangible and precise location of the experience portrayed both in terms of time and agency. The speaker of the poem insists on the lived quality of what is described and a humanly comprehensible timescale that goes with it, thus a stance is made for a concrete and determined position.

As Edna Longley observes, "[i]n Irish literature the past as a continuum looms larger than the past as mortality" (E. Longley The Living Stream, 150). The statement calls attention not only to the presence but the presentness of the past, since the idea of a continuum suggests a sense of permanence as opposed to the finiteness implied by the word mortality. Once the significance of the past is acknowledged, history becomes an integral part of the literary tradition. In the wake of James Joyce calling it a nightmare, history has indeed been a frequent element 
of Irish poetry, in various forms and with the frequent realisation of the close interconnectedness of the personal and the communal dimensions. The communal often exerts a constraining, occasionally even paralysing effect on the individual and his choices, which results in a menacing direct experience of history. History is not only something of which the individual can be a part but is a part-it is experienced from within. Myth, however, offers a different approach to experience as it is a stylised narrative of an elevated register that remains external and is contemplated from without, thus there is no direct experience of this on the part of the observer. This difference serves as a means of distancing, since as Roland Barthes claims, "[m]yth deprives the object of which it speaks of all History" (Barthes 152). The use of myth thus can act as a liberating move as it relocates the temporal element in a particular context, creating a general sense of the pastness of the past, paradoxically by the suspension of its exact determination.

The observation that male poets use myth "to create a 'usable past" and it indicates "a tendency to remove history from the realm of the every day" (Sarbin quoted in O'Mahony 138) is in concord with this idea. There is, however, an important emphasis on "male poets" here since female poets use myth or legend for a different purpose as their aim is "to move away from a 'distant idealized object to the real" (ibid). This difference in approach results from the conviction that Irish literary history leaves little space for women, so there is an observable preference for myth as opposed to that type of history (cf. Meaney 100). Rather than considering myth as a means of refining experience out of a definite timescale, myth becomes more of a concretising device for women poets than a means of abstraction, thus the choice of myth or history represents a different type of decision for them.

Whereas myth is understood as a narrative whose referent may be taken either literally or symbolically, the case of history is considered to be simpler as it is commonly regarded to be based in "fact." Yet history has its inherent dilemmas as well since the narrative that arises in the wake of the historian's effort has its own dubious implications: "[ $t$ ] he linear ordering of events into a narrative creates an illusion that it is possible to turn back and return to past events, which by virtue of their continuity in the hic et nunc acquire the status of mythical origins" (Jarniewicz 84). This renders historical narratives as capable of becoming the past itself, which is in strong contrast with the postmodern concept of history as discourse:

History is arguably a verbal artefact, a narrative discourse of which, après White, the content is as much invented as found, and which is constructed by present-minded, ideologically positioned workers (historians and those acting as if they were historians) operating at various levels of reflexivity... [The] past, appropriated by historians, is never the past itself ... the cogency of historical work 
can be admitted without the past per se ever entering into it - except rhetorically. In this way histories are fabricated without 'real' foundations beyond the textual [...]. (Jenkins quoted in E. Longley Poetry and Posterity, 289)

This approach to history gives the impression of being deprived of the past itself since being regarded as a purely rhetorical construct with only textual foundations it calls into question its very referent. While its nature as discourse may be acknowledged, history appears to retain its factual affiliations in general in the work of several poets, and the distinction between myth and history persists as a result.

The importance of the past in Irish literature becomes explicitly apparent when the expectation towards poets and writers is formulated on the occasion of certain events of generally acknowledged significance. One such example is the Northern Troubles, the instance when history becomes everyday reality and embodies the Joycean nightmare. From the outbreak of violence, the pressure, especially on Northern poets to address the situation and provide some form of assessment of it became tangible. As Seamus Heaney would remark, in the wake of the events of 1969, "[f] rom that moment the problems of poetry moved from being simply a matter of achieving the satisfactory verbal icon to being a search for images and symbols adequate to our predicament" (Heaney Preoccupations, 56).

Heaney's own response to the adversities of the Northern situation took the form of a tentative mythic framework in the collection North. Taking John Montague's The Rough Field as an example of the modern sequence-as-long-poem, Heaney made an attempt of locating the Northern conflict in a composite myth of a rather broad sweep, with a distinguished place reserved for a parallel with an Iron Age fertility cult based on P. V. Glob's account in The Bog People. The group of poems focusing on these figures has its own dynamism and is emblematic in itself of the evolution of Heaney's position as it contains its own deconstruction and explicitly admits its failure as an analogue. The structure of the whole volume reflects the latent doubt the possible mythic parallel involves as the myth-oriented first section is balanced by a personal-oriented second one, pointing towards not only the possibility but the necessity of revision. As a result, several poems in the subsequent volume Field Work dispense with the mythic dimension and employ figures of individuals, reflecting a shift of approach from myth to an explicitly private experience of "history."

This shift from myth to history in Heaney's assessment of the Northern conflict can be properly observed in the difference between the poems "The Tollund Man" and "Casualty". "The Tollund Man" is firmly anchored in myth and local legend - the Iron Age fertility cult exposed by the figure of the title becomes the imaginative analogue of the sectarian conflict evoked through figures of the local 
lore, culminating in an invocation to the sacrificial victim in the context of a proposed pilgrimage to his final resting place:

I could risk blasphemy,

Consecrate the cauldron bog

Our holy ground and pray

Him to make germinate

The scattered, ambushed

Flesh of labourers,

Stockinged corpses

Laid out in the farmyards,

Tell-tale skin and teeth

Flecking the sleepers

Of four young brothers, trailed

For miles along the lines. (Heaney New Selected Poems, 32)

The poem is tightly structured, the short and neat stanzas reflect the sombre mood of the myth and the speaker even acknowledges the potentially blasphemous act of drawing a parallel between the old pagan cult and the contemporary sectarian element. The closure of the poem eventually steps out of the public sphere of the suggested parallel and provides a more low-key personal conclusion:

Out there in Jutland

In the old man-killing parishes

I will feel lost,

Unhappy and at home. (ibid)

The situation of "Casualty" is markedly different since the apropos of the poem is the death of an acquaintance in an instance of sectarian violence. The personal dimension is indicated by the looser form as the poem is composed of paragraphs rather than of stanzas, and the language is close to the conversational. The construction of the image of the figure is circular as the speaker's recollection of his relation with the victim keeps shifting between the time preceding the death of the man and its aftermath. Although the brutally ironic phrasing of the outcome of Bloody Sunday recalls a public perspective, the poem essentially moves within the private domain of the speaker's own experience. Similarly to Heaney's tactics in "The Tollund Man", the poem contains an invocation to the victim yet there is still a marked difference between the two poems. The final act of commemoration, a recollection of a shared moment with the victim instead of taking part in his 
funeral, indicates a very different approach on part of the speaker as it reflects the speaker's act of 'breaking faith with the tribe', the eventual 'sin' of the victim, and the language rises to a more elevated register to communicate what is essentially an impossible wish that at once reflects an act of absolution on the part of the poet as a public speaker:

[...] that morning

When he took me in his boat,

The screw purling, turning

Indolent fathoms white,

I tasted freedom with him.

To get out early, haul

Steadily off the bottom,

Dispraise the catch, and smile

As you find a rhythm

Working you, slow mile by mile,

Into your proper haunt

Somewhere, well out, beyond. . .

Dawn-sniffing revenant,

Plodder through midnight rain,

Question me again. (Heaney New Selected Poems, 103)

One particularly important moment of public expectation for assessment was the 1994 IRA ceasefire announcement, leading to highly different responses by Heaney and fellow Northern poet Michael Longley. Heaney's answer was "Tollund", a poem with a contemporary setting relating a simple and straightforward account of a tourist visit to the place referred to in the title. The name, however, contains the unmistakeable allusion to the earlier poem focusing on the myth and the subsequent historical content that is brought together with it. The poem is an intriguing pair to the earlier one as its more leisurely moving longer lines group together into stanzas with rhymes, and the elegant allusion to a Shakespearean scene at the end broadens the field of reference to provide not only a contrast with "The Tollund Man" and its context but to reflect the optimism contained by the historic moment of the occasion of the poem. The tone is more relaxed and personal, and the resulting atmosphere of the poem is devoid of the claustrophobia of the tightly built and laconic earlier pair, as it is indicated in the closure of the poem:

[...] it was user-friendly outback

Where we stood footloose, at home beyond the tribe, 
More scouts than strangers, ghosts who'd walked abroad

Unfazed by light, to make a new beginning

And make a go of it, alive and sinning,

Ourselves again, free-willed again, not bad.

(Heaney The Spirit Level, 69)

While Heaney's response was essentially based in his own private experience, Michael Longley's poem "Ceasefire" is built on a different perspective as it recalls a scene from the Iliad. The poem focuses on the episode of Priam asking for the body of his deceased son from Achilles, an act of self-imposed and self-negating humbling in front of the enemy: "I get down on my knees and do what must be done / And kiss Achilles' hand, the killer of my son"” (M. Longley 225). The story shows the encounter as a moment of recognition: the enemies are transformed by the personal encounter, the humanity of the other is mutually recognised and though the tension is palpable, there is a sense of suspended time as the domestic event of dinner renders the broader context of the war a mere background element. The old king mourning his son moves the invincible hero out of his established zone to reveal his humanity, and though the context is never fully out of sight, the suggested domestic interior provides a strong sense of contrast with the harsh reality of the war within which the scene functions as an episode. The form of the poem serves as a reminder of this ambivalent situation as Longley transfers the epic scene into the world of the lyric, and the relocated experience is presented in the form of a sonnet, yet the rhyme scheme is curtailed, so the harmony implied by the self-enclosed form of the sonnet as a type of poem is deliberately avoided.

Longley's understanding of the public expectation towards poets to comment on the present conflict creates an uneasy situation for him. His need for the authentication of his position takes the form of either relying on the individual history of his father or on the modern rendering of classical myth. Rather than attempting an all-encompassing approach, his careful selection of specific episodes of the Troubles provides a more intimate perspective and thus requires a likewise more narrowly focused analogue. His renderings of some contemporary events employ the figure of his father understood as a belated casualty of war, which enables the poet to address victims of the contemporary conflict through the direct experience of the tragedy of his own relative. The objective correlative of the father locates the present in relation to the personal history of the speaker which is eventually linked to and determined by the communal experience of the world war. This perspective is employed in the poem "Wounds", which renders side by side memories of the participation of the father in the war with quick images of casualties of the recent conflict. The historical dimension serves a double aim as it authenticates the pri- 
vate speaker's voice for commenting on the communal present and at the same time it also reveals the tragic absurdity of the contemporary violence.

Longley widely used allusions to myth and classical literature already at the beginning of his career yet these did little more than reflect his interest in the classical tradition. In the course of the 1990s explicit references to such material return to his poetry, as an alternative to the figure of the father as a motif in his response to the present. The most notable instance of this is "Ceasefire", yet the closing poem of the collection Gorse Fires, entitled "The Butchers" is a similar construct. That poem recounts the closing of the Odyssey, when the returning Odysseus dispenses with the suitors, yet Longley resituates the story by turning it into a lyric piece. In the light of contemporary experience, the result is a subversion of the mythic, the calling into question of the accepted "justice" of the original story, which is already marked by the title of the poem. Although there is no explicit linking of past and present, the contemporary is hinted at by such phrases as "disinfectant" (M. Longley 194) or the unmistakeably local terms "sheughs", "bog-meadow" and "bog-asphodel" (ibid). Longley's decision to render the story in the form of one single sentence has a rather particular effect on the sense of time as it is stretched out and is seemingly suspended as a result, which is an act of recreating the timeless atmosphere of myth, as well as providing a comment on the ongoing conflict of the present of which it thus also functions as an analogue.

Whereas the choice between myth and history is closely related to the present conflict for the two Northern poets, it is motivated by a very different reason for Eavan Boland. The woman poet's personal experience of the sense of being excluded from history prompts an interest in myth instead-the association of the concept of history with that of Irish literary history and its hostility towards women does not prove an attractive element. Myth, however, is devoid of similar constraints, and by its status as a narrative of undetermined time it offers a range of possibilities as an analogue for the poet, yet in a different way than it would for her male contemporaries. For them myth points beyond the concrete and defined temporal dimension of past events and thus lends a different degree of dignity to the experience assessed with the help of myth, creating the sense of the general rather than that of the particular in relation to it. The challenging of this tradition on the part of women poets leads to that unusual approach that is mentioned by Deborah Sarbin, that myth serves rather as a device of concretising and the distancing of an abstract ideal than the detachment of the past from the present (cf. Sarbin quoted in O’Mahony 138).

In spite of the specific problem of history, there is a definite moment when it is favoured over the mythic. In the poem "Outside History" the word 'history' becomes synonymous with being involved and participating, and it appears as 
the expression of existence in time. The contemplation of the stars takes an unusual turn as it is not their sublime existence that is noticed but their irrelevance to human matters by virtue of their incomprehensible distance both in terms of space and time. It is the latter idea that drives the rest of the poem forward, which introduces the concept of myth into the poem as an analogue to the timeless. The speaker makes a choice in favour of the temporality of history based on the implied contrast of the temporal versus the timeless: the choice is motivated by the understanding that human life is inescapably temporal therefore its proper frame has to be history as myth cannot adequately express human experience.

In the poem "Time and Violence" the temporal is likewise fronted to contrast with a specific tradition of stylised timelessness. The matter-of-fact description of a usual spring evening is disrupted by the visionary appearance of two figures, a shepherdess and a mermaid, and it is their experience of timelessness which is focused on as opposed to the one imposed on them by the traditions that they are a part of. The shepherdess is a representative of the pastoral, whereas the mermaid is associated with myth, and although the two traditions diverge, they share the association with the timeless. In Boland's poem the speaker's experience of these two figures is radically different from the commonly assumed one as they are seen from a human position, which makes the effects of the passing of time visible even for these supposedly timeless figures. The shepherdess is bruised, "her smile cracked / her arm injured from the mantelpieces / and pastorals where she posed with her crook" (Boland 238), and the mermaid likewise shows explicit physical consequences of the effects of time, "her breasts printed with the salt of it and all / the desolation of the North Sea in her face" (ibid). The voice heard at the end of the poem makes language responsible for this situation, the encrypting of these two figures into traditions that seek to eliminate the temporal constraints from experience and thus make it universal. Yet the timeless figure essentially falsifies human experience by the illusion of suspended time, and Boland calls attention to this by a rather ingenious manoeuvre as here the suspension of time is only partial, and consequently the sensory experience is only partly present as some of the external effects of passing time are shown, yet their human emotional content is missing. In this way the commonly regarded image of timelessness is subverted, these figures are not changeless either but their change is not complemented by "mortal pain" (Boland 239), and consequently by mortal joy either. The implied preference is thus for history, personal and private as it may be, yet the begging of the two figures reinforces the choice of the earlier poem in favour of a humanly comprehensible temporal framework for experience.

Both myth and history serve as analogues for Heaney and Longley for addressing the Troubles, in general terms as well as in relation to particular events. The 
two poets rely on both elements in their repeated assessments of the contemporary situation, yet they take different approaches: Heaney moves from myth to history, whereas Longley exchanges the personal historical dimension for a mythic one. Heaney's attempt of placing the events and the ethos of the Troubles in a broader mythic framework would eventually deconstruct itself to admit the unsatisfactory parallel between the envisioned past and the actual present, thus a turn to a more tangible experience of the latter would take the form of substituting history for myth, and the scope of the poems becomes narrower as the personal dimension is foregrounded. Longley's path is the opposite as he focuses on particular events with the historical analogue of his father's figure and moves on to a broader focus through allusions to classical literature and myth.

Eavan Boland is less concerned with an immediate present reference when using myth or history, as her choice is principally motivated by her position in relation to the Irish literary tradition. Her choice of history is a defiant act of revision in relation to the tradition that marginalises her as a woman poet as well as a careful reconsideration of the function of signposts for relating experience expressed in poetry. Though myth provides the opportunity of challenging the marginal position assigned to her as a woman poet, the contrast between myth and history eventually becomes the general antagonism between the timeless and the temporal. In this way her preference lies with history since her poems always carefully frame experience as a function of time and it is history that provides the adequate temporal framework for human experience. The timeless suggestion of myth may be tempting but critical observation and recording are entangled with the notion of history both as expression of a humanly comprehensible timeframe and a liveable experience of chronology.

\section{Works Cited}

Barthes, Roland. 1972. Mythologies. New York: The Noonday Press.

Boland, Eavan. 2008. New Collected Poems. New York: W.W. Norton \& Company.

Heaney, Seamus. 1990. New Selected Poems 1966-1987. London: Faber.

Heaney, Seamus. 1981. Preoccupations: Selected Prose 1968-1978. New York: Farrar, Straus and Giroux.

Heaney, Seamus. 1996. The Spirit Level. London: Faber. 
Jarniewicz, Jerzy. 2002. "Derek Mahon: History, Mute Phenomena and Beyond. In The Poetry of Derek Mahon, edited by Elmer Kennedy-Andrews, 83-95. Gerrards Cross: Colin Smythe Limited.

Kirkland, Richard. 1996. Literature and Culture in Northern Ireland Since 1965: Moments of Danger. London: Longman.

Longley, Edna. 1994. The Living Stream. Literature and Revisionism in Ireland. Newcastle: Bloodaxe.

Longley, Edna. 2000. Poetry and Posterity. Newcastle: Blooadaxe.

Longley, Michael. 2006. Collected Poems. London: Cape Poetry.

Meaney, Gerardine. 1995. "History Gasps: Myth in Contemporary Irish Women's Poetry." In Poetry in Contemporary Irish Literature, edited by Michael Kenneally, 99-113. Gerrards Cross: Colin Smythe.

O'Mahony, Nessa. 2017. “'The only legend I have ever loved': Classical Mythology and the Ceres Legend in the Poetry of Eavan Boland." In Eavan Boland: Inside History, edited by Siobhan Campbell and Nessa O'Mahony, 137-152. Dublin: Arlen House. 